\title{
ANALISIS PENGELOLAAN LIMBAH CAIR USAHA LAUNDRY
}

\author{
Yusmidiarti
Politeknik Kesehatan Kementerian Kesehatan Bengkulu, Jurusan Kesehatan Lingkungan, Jalan Indragiri Nomor 03 Padang Harapan Kota Bengkulu
yusmi_tegar@yahoo.co.id

\begin{abstract}
Washing clothes and other household appliances (laundry) is one of businesses that ease the burden on society in terms of domesticity. Urban communities, especially those having activities outside home are relatively dense prefer to take advantage of laundry services. The appearance of the laundry business is to provide the advantages and the solutions on household work, also provide new jobs for people in the surrounding area. But advantage gained is inversely proportional to the quality of resulting environment. The proliferation of laundry services will worsen the quality of the surrounding water because this business is not equipped with waste treatment processes but is discharged directly into sewers or water bodies nearby. As a result of laundry waste discharged into water bodies continuously without being processed, it may cause water pollution problems. The result of research that gained in the implementation of waste management obligations by some laundry business in Bengkulu city as meticulous in environmental pollution control measures, has not done well and the lack of awareness and knowledge about the dangers of toxic waste generated laundry business and the lack of government attention to the laundry business growth impact in Bengkulu City.
\end{abstract}

Keywords: Laundry, Detergent, Environmental

\begin{abstract}
Abstrak : Pencucian pakaian dan alat rumah tangga lainnya (laundry) merupakan salah satu usaha yang meringankan beban masyarakat dalam hal kerumahtanggaan. Masyarakat perkotaan, terutama yang memiliki kegiatan diluar rumah relatif padat lebih memilih untuk memanfaatkan jasa laundry. Kemunculan usaha laundry ini selain dapat memberikan keuntungan dan merupakan solusi pekerjaan kerumahtanggaan, juga memberikan lapangan pekerjaan baru bagi masyarakat daerah sekitarnya. Namun keuntungan yang diperoleh ini berbanding terbalik dengan kualitas lingkungan yang dihasilkan. Menjamurnya jasa laundry akan memperburuk kualitas air di sekitarnya karena usaha ini tidak dilengkapi dengan proses pengolahan limbahnya melainkan dibuang langsung ke selokan maupun badan air terdekat. Akibat limbah laundry yang dibuang ke badan air secara terus menerus tanpa diolah, dapat menimbulkan masalah pencemaran air. Hasil penelitian yang dilakasanakan didapatkan pelaksanaan kewajiban pengelolaan limbah oleh beberapa usaha laundry yang di teliti di Kota Bengkulu sebagai langkah pengendalian pencemaran lingkungan, belum terlaksana dengan baik dan Kurangnya kesadaran dan pengetahuan mengenai bahaya limbah beracun yang dihasilkan usaha laundry serta belum adanya perhatian khusus dari pemerintah terhadap dampak pertumbuhan usaha laundry di Kota Bengkulu.
\end{abstract}

Kata kunci : Laundry, Detergen, Lingkungan

Jumlah penduduk yang meningkat secara signifikan menyebabkan terjadi peningkatan kebutuhan akan barang dan jasa untuk meringankan beban kerumahtanggaan. Pencucian pakaian dan alat rumah tangga lainnya (laundry) merupakan salah satu usaha yang meringankan beban masyarakat dalam hal kerumahtanggaan. Masyarakat perkotaan, terutama yang memiliki kegiatan diluar rumah relatif padat lebih memilih untuk memanfaatkan jasa laundry. Kemunculan usaha laundry ini selain dapat memberikan keuntungan dan merupakan solusi pekerjaan kerumahtanggaan, juga memberikan lapangan pekerjaan baru bagi masyarakat daerah sekitarnya. Namun keuntungan yang diper- 
oleh ini berbanding terbalik dengan kualitas lingkungan yang dihasilkan. Menjamurnya jasa laundry akan memperburuk kualitas air di sekitarnya karena usaha ini tidak dilengkapi dengan proses pengolahan limbahnya melainkan dibuang langsung ke selokan maupun badan air terdekat. Akibat limbah laundry yang dibuang ke badan air secara terus menerus tanpa diolah, dapat menimbulkan masalah pencemaran air.

Air buangan sisa detergen dapat menimbulkan permasalahan serius karena produk detergen dan bahan-bahan kimianya dapat berakibat toxic bagi kehidupan dalam air. Air buangan sisa detergen yang dihasilkan dalam volume besar sangat berbahaya untuk kelestarian sungai dan tanah. Karena sifatnya yang kompleks, air limbah detergen/laundry sangat sukar untuk diolah. Kebutuhan air untuk industri laundry ratarata $15 \mathrm{~L}$ untuk memproses $1 \mathrm{~kg}$ pakaian dan menghasilkan sekitar $400 \mathrm{~m} 3$ limbah cair per hari (Ciabatti, 2009).

Pencemaran air oleh limbah laundry terutama disebabkan oleh keberadaan fosfat dalam limbah laundry. Keberadaan fosfat yang berlebihan di badan air menyebabkan suatu fenomena yang disebut eutrofikasi (pengkayaan nutrien). Masalah eutrofikasi baru disadari pada dekade awal abad ke-20 saat algae banyak tumbuh di ekosistem air. Masalah ini disinyalir akibat langsung dari aliran limbah yang mengandung fosfat tinggi. Fosfat merupakan elemen kunci diantara nutrient utama didalam proses eutrofikasi selain karbon $(\mathrm{C})$ dan nitrogen $(\mathrm{N})$.

Survey awal di yang dilakukan pada salah satu laundry di Kota Bengkulu, diketahui usaha laundry belum melaksanakan kewajiban pengelolaan limbah cair laundry. Usaha laundry tersebut belum mengolah limbah cair yang dihasilkan, limbah cair laundry langsung dibuang ke saluran air dan belum memiliki perizinan pendirian usaha laundry.

Bahan kimia pada air limbah laundry terutama berasal dari detergen yang digunakan. Komposisi kimia dalam detergen dapat dikelompokkan menjadi 3 kelompok, yaitu zat aktif permukaan (surfaktan) berkisar 20-
$30 \%$, bahan penguat (builder) merupakan komponen terbesar dari detergen berkisar 70-80 \% dan bahan-bahan lainnya (pemutih, pewangi, bahan penimbul busa dan optical brightener) sekitar 2-8 \%, dimana surfaktan merupakan bahan pembersih utama dalam detergen.

Untuk mengurangi dampak yang di akibatkan oleh limbah cair usah laundry, pemerintah telah mengeluarkan berbagai peraturan yang berhubungan dengan masalah Lingkungan Hidup, salah satunya Peraturan Pemerintah Nomor 18 Tahun 1999 Tentang Pengelolaan Limbah Berbahaya dan Beracun (B3) dan Peraturan Pemerintah Republik Indonesia Nomor 82 Tahun 2001 Tentang Pengelolaan Kualitas Air dan Pengendalian Pencemaran Air. Didalam Peraturan Pemerintah Nomor 18 Tahun 1999 telah diatur antara lain limbah yang dihasilkan oleh suatu kegiatan (misal: industri) yang dibuang ke lingkungan (udara dan perairan) harus sesuai dengan baku mutu lingkungan hidup.

\section{BAHAN DAN CARA KERJA}

Penelitian ini menggunakan metode analisis kualitatif dengan jenis penelitian berupa penelitian survey deskriptif yang dilakukan dengan cara observasi dan wawancara untuk mengetahui gambaran pelaksanaan pengelolaan limbah cair laundry, pelaksanaan kewajiban (SOP) pengelolaan limbah cair laundry dan pengetahuan pengusaha limbah laundry tentang dampak limbah cair laundry yang dihasilkan serta dampak limbah cair laundry terhadap masyarakat.

\section{HASIL}

Hasil pelaksanaan observasi dan kuesioner yang berisi pertanyaan tentang pelaksanaan pengelolaan limbah cair laundry, kewajiban usaha laundry (perizinan usaha laundry) dan pengetahuan pengusaha laundry tentang limbah laundry disajikan dalam bentuk tabel distribusi frekuensi.

Berdasarkan Tabel 1 Hasil Tabulasi Observasi dan Kuesioner Pelaksanaan Pengelolaan Limbah Cair Usaha Laundry Di 
Kota Bengkulu didapatkan hasil 30,61\% yang memenuhi syarat dan $69,39 \%$ yang tidak memenuhi syarat. Kewajiban Usaha Laundry Limbah Cair Usaha Laundry Di Kota Bengkulu didapatkan hasil $75.51 \%$ yang memiliki izin dan $24.49 \%$ yang tidak memiliki izin. Pengetahuan Pengusaha Laundry Tentang Limbah Laundry. Didapatkan hasil $100 \%$ yang memiliki pengetahuan yang baik dan $0 \%$ yang kurang baik.

Tabel 1. Gambaran pelaksanaan, kewajiban dan pengetahuan pengusaha loundry

\begin{tabular}{|c|c|c|}
\hline Pertanyaan & $\begin{array}{c}\text { Frekuensi } \\
(f=49)\end{array}$ & $\begin{array}{l}\text { Presentase } \\
(100 \%)\end{array}$ \\
\hline \multicolumn{3}{|c|}{ Pelaksanaan Pengelolaan Limbah cair Usaha Laundry } \\
\hline Memenuhi Syarat & 15 & 30.61 \\
\hline Tidak Memenuhi & 34 & 69.39 \\
\hline \multicolumn{3}{|c|}{$\begin{array}{l}\text { Syarat } \\
\text { apakah limbah usaha laundry dapat mencemari air } \\
\text { sumur }\end{array}$} \\
\hline $\mathrm{Ya}$ & 61.22 & 61.22 \\
\hline Tidak & 38.78 & 38.78 \\
\hline \multicolumn{3}{|c|}{ Kewajiban Usaha Laundry (Perizinan Usaha Laundry) } \\
\hline Memiliki Izin & 37 & 75.51 \\
\hline Tidak Memiliki Izin & 12 & 24.49 \\
\hline $\begin{array}{l}\text { Pengetahuan Pengusah } \\
\text { Laundry }\end{array}$ & a Laundry & Tentang Limbah \\
\hline Baik & 14 & 100 \\
\hline Kurang Baik & 35 & 0 \\
\hline
\end{tabular}

Berdasarkan tabel 2 Hasil tabulasi pada pertanyaan Apakah ada keluhan kesehatan kulit saat menggunakan air sumur. Masyarakat menjawab ya percentage $63,27 \%$ dan menjawab tidak $36,73 \%$. Air sumur yang digunakan masyarakat sekitar usaha laundry mengakibatkan masyarakat sekitar mengeluh kesehatan kulit dengan percentage $63,27 \%$.

Hasil tabulasi pada pertanyaan "Menurut anda apakah limbah usaha laundry dapat mencemari air sumur. Masyarakat menjawab ya percentage $61,22 \%$ dan menjawab tidak 38,78\%. Masyarakat sekitar usaha laundry lebih banyak menjawab ya dibandingkan tidak.

Hasil tabulasi pada pertanyaan "Apakah limbah cair laundry yang dialirkan sembarangan mengganggu bapak/ibu. Masyarakat sekitar usaha laundry berpendapat limbah cair yang dialirkan sembarangan menjawab ya mengganggu dengan percenttage $53.06 \%$ dan menjawab tidak $46.94 \%$.
Hasil tabulasi pada pertanyaan "Menurut anda apakah limbah usaha laundry berbahaya bagi kesehatan. Masyarakat sekitar usaha laundry berpendapat limbah usaha laundry berbahaya bagi kesehatan dengan percentage $100 \%$ menjawab ya berbahaya bagi kesehatan.

Hasil tabulasi pada pertanyaan "Menurut anda apakah limbah usaha laundry berbahaya bagi lingkuingan. Masyarakat sekitar usaha laundry berpendapat limbah usaha laundry berbahaya bagi lingkungan dengan percentage $100 \%$ menjawab ya berbahaya bagi lingkungan.

Tabel 2. Masalah Dampak Limbah Cair Laundry.

\begin{tabular}{|c|c|c|}
\hline Pertanyaan & $\begin{array}{l}\text { ekuensi } \\
(\mathrm{f}=49)\end{array}$ & $\begin{array}{l}\text { Presentase } \\
(\mathbf{1 0 0 \%})\end{array}$ \\
\hline \multicolumn{3}{|c|}{$\begin{array}{l}\text { Apakah ada keluhan kesehatan kulit saat menggunakan } \\
\text { air sumur }\end{array}$} \\
\hline Ya & 31 & 63.27 \\
\hline \multicolumn{3}{|c|}{$\begin{array}{l}\text { apakah limbah usaha laundry dapat mencemari air } \\
\text { sumur }\end{array}$} \\
\hline $\mathrm{Ya}$ & 61.22 & 61.22 \\
\hline Tidak & 38.78 & 38.78 \\
\hline $\begin{array}{l}\text { Apakah limbah cair } \\
\text { sembarangan mengganggu }\end{array}$ & $\begin{array}{l}\text { laundry } \\
\text { bapak/ibu }\end{array}$ & yang dialirkan \\
\hline $\mathrm{Ya}$ & 26 & 53.06 \\
\hline Tidak & 23 & 46.94 \\
\hline $\begin{array}{l}\text { Apakah limbah usaha } \\
\text { kesehatan }\end{array}$ & laundry & berbahaya bagi \\
\hline $\mathrm{Ya}$ & 49 & 100 \\
\hline Tidak & 0 & 0 \\
\hline $\begin{array}{l}\text { Apakah limbah usaha } \\
\text { lingkuingan }\end{array}$ & laundry & berbahaya \\
\hline $\mathrm{Ya}$ & 49 & 100 \\
\hline Tidak & 0 & 0 \\
\hline
\end{tabular}

\section{PEMBAHASAN}

Hasil pelaksanaan observasi dan kuesioner yang berisi pertanyaan tentang pelaksanaan pengelolaan limbah cair laundry, kewajiban usaha laundry (perizinan usaha laundry) dan pengetahuan pengusaha laundry tentang limbah laundry disajikan dalam bentuk narasi. Analisis data yang terkumpul dilakukan secara deskriptif yang disajikan dalam bentuk narasi, sehingga diperoleh hasil Analisis limbah cair usaha laundry di Kota Bengkulu.

Usaha laundry dikota Bengkulu lebih banyak yang tidak memenuhi syarat. Dari hasil wawancara yang dilaksanakan terhadap pemilik usaha laundry, hanya sebagian usaha laundry yang memiliki instalasi 
pengolahan limbah cair. Instalasi pengolahan cair yang umum digunakan adalah kolam oksidasi. Limbah cair usaha laundry ditampung di kolam oksidasi dan dibiarkan terkena sinar matahari sehingga terjadi peristiwa aerob. Limbah cair laundry akan tedegrasi melalui bantuan sinar matahari dan oksigen bebas. Selanjutnya dibuang ke lingkungan. Belum ada usaha laundry yang memiliki instalasi pengolahan limbah cair laundry. Usaha laundry di kota Bengkulu ini beberapa hanya menyediakan bak yang berfungsi sebagai penampungan limbah cair usaha laundry. Hanya dibiarkan kontak dengan sinar matahari dan udara bebas. Prinsip ini merupakan pengolahan limbah cair menggunakan kolam oksidasi. Sehingga bahan kimia dan organik dalam limbah cair akan terdegrasi dengan sinar matahari dan udara bebas.

Dalam segi perizinan usaha laundry kota Bengkulu Berdasarkan Kuesioner Kewajiban Usaha Laundry Limbah Cair Usaha Laundry Di Kota Bengkulu. Sebagian besar usaha laundry sudah memiliki izin usaha. Perizinan merupakan instrumen hukum lingkungan yang mempunyai fungsi preventif, yaitu mencegah terjadinya pencemaran dan kerusakan lingkungan. Sebagian belum memiliki izin dan ada yang dalam proses kepengurusan di kantor KP2T dan BLH Kota Bengkulu. Beberapa usaha laundry yang belum memiliki izin merupakan usaha laundry yang baru menjalankan usaha, seperti usaha laundry yang berada di daerah padang dedok. Berdiri di tahun 2014 sehingga masih memiliki kekurangan yang harus dipenuhi sehingga perizinan bisa dikeluarkan oleh kantor KP2T dan BLH.

Dalam usaha jasa laundry minimal mempunyai $\mathrm{HO}$ atau izin gangguan yang didapatkan dari Kantor Pelayanan Perizinan Terpadu (KP2T) di daerah tempat usaha tersebut didirikan. Berdasarkan Undangundang No 32 Tahun 2009 Tentang Pengelolaan Lingkungan Hidup Pasal 35 ayat 1 berbunyi Setiap Usaha dan/atau kegiatan yang tidak wajib dilengkapi UKL UPL sebagaimana dimaksud dalam Pasal 34 ayat (2) wajib membuat surat pernyataan kesang- gupan pengelolaan dan pemantauan lingkungan hidup.

Gambaran pengetahuan yang dimiliki oleh pengusaha laundry, Dari hasil pengisian kuesioner didapatkan sebagian besar pengusaha laundry Kota Bengkulu memiliki pengetahuan yang cukup tentang usaha laundry yang mereka jalankan. Pengusaha laundry sebagian besar sudah mengetahui cara yang benar dalam mengolah limbah cair yang dihasilkan dari usaha laundry yang dijalankan. Pertanyaan yang kurang mampu dijawab oleh pemilik usaha laundry adalah kandungan detergen. Pemilik usaha laundry tidak memahami unsur kimia yang terkandung di dalam limbah detergen.

Limbah detergen akan memberi dampak yang buruk bagi kesehatan. Bahan kimia dalam detergen mengandung unsur kimia yang berbahaya yaitu yang paling berbahaya adalah dari golongan ammonium kuartener, senyawa ini dapat membentuk senyawa nitrosamin. Senyawa nitrosamin diketahui bersifat karsinogenik yang dapat menyebabkan kanker. Limbah detergen juga dapat menyebabkan iritasi (panas, gatal bahkan mengelupas) pada kulit terutama di daerah yang bersentuhan langsung dengan produk. Untuk produk detergen yang memiliki derajat keasaman $(\mathrm{pH})$ tinggi.

Dari hasil wawancara yang dilaksanakan didapatkan semua masyarakat yang berada di sekitar laundry berpendapat limbah usaha laundry berbahaya bagi kesehatan. Walaupun belum terlihat secara langsung bahaya yang ditimbulkan karena hanya beberapa masyarakat saja yang mengeluh terkena penyakit kulit dari sumur yang mereka gunakan. Keluhan masyarakat yang mengeluh sumurnya tercemar limbah laundry hanya beberapa masyarakat saja.

Limbah cair laundry yang dibuang langsung kelingkungan dapat mencemari air tanah, limbah cair akan merembes dan mengakibatkan tercemarlah air tanah. Limbah cair laundry menimbulkan permasalahan serius karena produk deterjen dan bahanbahan ingredientnya menyebabkan toxic bagi kehidupan dalam air. Jelaslah bahwa air buangan sisa deterjen yang dihasilkan 
dalam volume besar sangat berbahaya untuk kelestarian sungai dan tanah. Proses laundry menghasilkan limbah cair yang berasal dari bleaching (pemucat), water softener, dan surfactant (Turk et al 2005).

\section{KESIMPULAN}

Pelaksanaan kewajiban pengelolaan limbah oleh beberapa usaha laundry yang di teliti di Kota Bengkulu sebagai langkah pengendalian pencemaran lingkungan, belum terlaksana dengan baik. Kendala yang dihadapi pengelola usaha laundry adalah adanya keterbatasan dana oleh masing-

\section{DAFTAR RUJUKAN}

Ahmad. R., 2004. Kimia Lingkungan. Yogyakarta : Andi.

Bahl, B.S., G.D Tuli \& A.Bahl, 1997, Essential of Pysical Chemistry. New Delhi : S.Chand and Company, Ltd.

Bhattacharya, C. B. \& Luo, X. 2006. Corporate Social Responsibility, Customer Satisfaction, and Market Value. Journal of Marketing. New Delhi : S.Chand and Company, Ltd.

Ciabatti, I, F. Cesaro, L.Faralli, E.Fatrella, \& F.Togotti, 2009. Demonstration of a treatment system for purification and reuse of laundry wastewater, Desalination. Jakarta : Penebar swadaya.

Dede, Ibrahim. 2007. Analisa COD dari Campuran Limbah Domestik dan Laboratorium di Balai Riset dan Standarisasi Industri Medan. Skripsi. Medan : Universitas Sumatera Utara

Fardiaz, S., 2008. Mikrobiologi Pangan I. Jakarta : Gramedia Pustaka Utama.

Ginting, Ir. Perdana. 2007. Sistem Pengelolaan Lingkungan Dan Limbah Industri, Cetakan pertama. Bandung: Yrama Widya.

Haghi, A.K., 2010. Waste Management. Canada : Nova Science.

Haryanto, R., dan Kusumah. K.D., 2001. Sedimentasi Batuan Pembawa Batubara Formasi Talang Akar di Daerah Lubuk Madrasah, Subcekungan Jambi. Bandung : P3G.

Hines, A.L., \& Robert N. Maddox, 1985. Mass Transfer Fundamental and Aplications. New Jersey : Prontice Hall Inc.

Keputusan Menteri Lingkungan Hidup No.58 Tahun 1995 tentang Baku Mutu Limbah Cair Bagi Kegiatan Rumah Sakit. Jakarta : Kementerian Lingkungan Hidup.

Kusnaedi, 2006. Mengolah Air gambut dan air kotor untuk air minum. Jakarta : Penebar swadaya. masing pengelola laundry untuk mengadakan Instalasi Pembuangan Air limbah secara pribadi. Kurangnya kesadaran dan pengetahuan mengenai bahaya limbah beracun yang dihasilkan usaha laundrynya serta belum adanya perhatian khusus dari pemerintah terhadap dampak pertumbuhan usaha laundry di Kota Bengkulu.

Diharapkan Pemerintah di Kota Bengkulu perlu melakukan penyuluhan dan penertiban terhadap pengelola usaha laundry yang membuang limbahnya langsung ke selokan air tanpa proses.

Muhdarina, A.L., 2003. Pilarisasi Kaolinit Alam untuk meningkatkan Kapasitas Tukar Kation. Jurnal Natur Indonesia, (Online). http//google.com, diakses 27 Februari 2014.

Nasruddin, 2005. Dynamic Modeling and Simulation of a Two-Bed Silicagel-Water Adsorption Chiller. Disertation. Germany : Rwth Aachen.

Suarmin, Nusa Idaman., 2011. Pengelolaan Limbah Domestik. Jakarta : BPPT.

Smulders, E. 2002. Laundry Detergents. Germany : Wiley - VCH Verlag GmbH Weinheim.

Sostar-Turk, S., Petrini, I., dan Simoni, M., (2005), Laundry wastewater treatment using coagulation and membrane filtration, Resources, Conservation and Recycling.

Sugiharto, 2008. Dasar-Dasar Pengelolaan Air Limbah, Jakarta : Penerbit Universitas Indonesia (UI-Press).

Suharty. 2011. Analisis Kadar Fosfat Limbah Cair Laundry di Rumah Sakit Umum Martha Friska Medan. Skripsi. Medan : Universitas Sumatera Utara

Suharto, Ign. 2010. Limbah Kimia dalam Pencemaran Udara dan Air. Yogyakarta : Penerbit Andi.

Susana, 2009. Detergen dan Kandungan nya, (Online). http://green.kompasiana.com, diakses 27 Februari 2014.

Wibawa ,2009. Detergen dan Kandungan nya, (Online). http://green.kompasiana.com, diakses 27 Februari 2014.

Zahri, 2005. Detergen dan Kandungan nya, (Online). http://green.kompasiana.com, diakses 27 Februari 2014.

Wardhana, Wisnu Arya. (2004). Dampak Pencemaran Lingkungan. Yogyakarta: Andi 